\title{
OPEN Skin irritation and potential antioxidant, anti-collagenase, and anti-elastase activities of edible insect extracts
}

\author{
Kankanit Yeerong ${ }^{1}$, Suwannee Sriyab ${ }^{1}$, Suvimol Somwongin ${ }^{1}$, Chanun Punyoyai ${ }^{1}$, \\ Panuwan Chantawannakul ${ }^{2}$, Songyot Anuchapreeda ${ }^{3,4}$, Adchara Prommaban ${ }^{1} \&$ \\ Wantida Chaiyana ${ }^{1,4,5} \bowtie$
}

This study aimed to investigate antioxidant, anti-aging, and irritation properties of Thai edible insect extracts, including Bombyx mori, Omphisa fuscidentalis, Euconocephalus sp., Patanga succincta, Acheta domesticus, and Lethocerus indicus. Insects were extracted by 2 different methods, including maceration using ethanol or hexane and digestion using DI water. Then the extracts were determined for protein content using bicinchoninic acid assay and antioxidant activities using 2,2'-azinobis (3-ethylbenzothiazoline-6-sulfonic acid), 2,2-diphenyl-1-picrylhydrazyl, ferric reducing antioxidant power, and ferric thiocyanate assays. Anti-aging activities were investigated by determination of collagenase and elastase inhibitory activities using spectrophotometric assay. Maceration by hexane yielded the highest extract content, whereas aqueous extract from digestion possessed the significantly highest protein content and biological activities $(p<0.05)$. Interestingly, aqueous extracts of $A$. domesticus possessed the significantly highest biological activities $(p<0.05)$ with Trolox equivalent antioxidant capacity value of $8.8 \pm 0.1 \mathrm{mmol}$ Trolox $/ \mathrm{mg}$, DPPH inhibition of $19.5 \pm 3.8 \%$, equivalent concentration of $12.1 \pm 0.7 \mu \mathrm{M} \mathrm{FeSO}_{4} / \mathrm{mg}$, lipid peroxidation inhibition of $31.3 \pm 2.4 \%$, collagenase inhibition of $60.8 \pm 2.1 \%$, elastase inhibition of $17.0 \pm 0.1 \%$, and no irritation effect on chorioallantoic membrane and volunteers. Therefore, aqueous extract of $A$. domesticus would be suggested for further topical product development.

Insects, an arthropod in the class of Insecta and subphylum of Hexapoda, not only play an important role in the world ecology system, but also are a rich source of proteins, lipids, carbohydrates, minerals, and vitamins ${ }^{1,2}$. Nowadays, insects are a new source of animal-based protein that could overcome serious worldwide nutrition problems and deficiency of good quality protein for low-income people ${ }^{3}$. Approximately 1500-2000 species of insects are consumed by 3000 ethnic groups across 113 countries in Asia, Africa, Australia, and Latin America ${ }^{1,2}$. In Thailand, insects in a wide range of insect family, such as Tettigoniidae, Crambidae, Gryllidae, Bombycidae, Acrididae, Belostomatidae, etc. are consumed. Bamboo caterpillar (Omphisa fuscidentalis; Family: Crambidae) and silkworm pupae (Bombyx mori; Family: Bombycidae) are the most popular edible insects ${ }^{4}$. Grasshopper (Euconocephalus sp.; Family: Tettigoniidae), Bombay locust (Patanga succincta: Family: Acrididae), house cricket (Acheta domesticus; Family: Gryllidae), and giant water bug (Lethocerus indicus; Family: Belostomatidae) are also widely consumed throughout the country. The nutritional values of Thai edible insects have already been reported ${ }^{4}$. The $O$. fuscidentalis could provide the highest calories $(231 \mathrm{kcal} / 100 \mathrm{~g})$ since it contains the highest amount of fat (20.4\%), whereas P. succincta contains a small amount of fat (4.7\%) but it is rich in protein content $(27.6 \%)$.

\footnotetext{
${ }^{1}$ Department of Pharmaceutical Sciences, Faculty of Pharmacy, Chiang Mai University, Chiang Mai 50200, Thailand. ${ }^{2}$ Bee Protection Laboratory, Department of Biology, Faculty of Science, Chiang Mai University, Chiang Mai 50200, Thailand. ${ }^{3}$ Division of Clinical Microscopy, Department of Medical Technology, Faculty of Associated Medical Sciences, Chiang Mai University, Chiang Mai 50200, Thailand. ${ }^{4}$ Research Center of Pharmaceutical Nanotechnology, Faculty of Pharmacy, Chiang Mai University, Chiang Mai 50200, Thailand. ${ }^{5}$ Innovation Center for Holistic Health, Nutraceuticals, and Cosmeceuticals, Faculty of Pharmacy, Chiang Mai University, Chiang Mai 50200, Thailand. ${ }^{\varpi}$ email:Wantida.chaiyana@gmail.com
} 
(a)

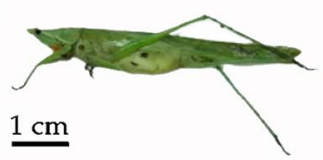

(b)

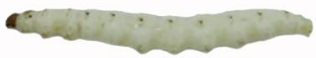

$\underline{1 \mathrm{~cm}}$ (c)

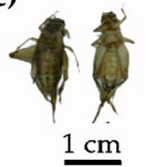

(d)

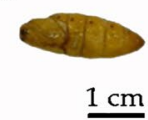

(e)

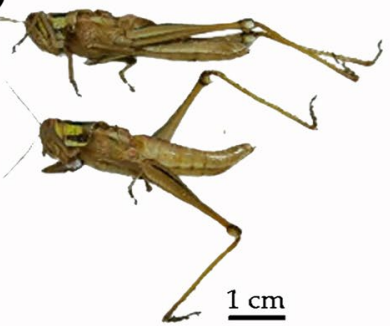

(f)

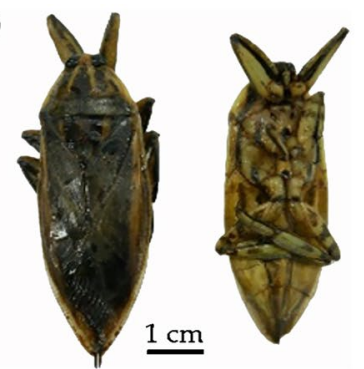

Figure 1. External appearances of Thai edible insects, including (a) rice grasshopper (Euconocephalus sp.), (b) bamboo caterpillar (O. fuscidentalis), (c) house cricket (A. domesticus), (d) silkworm pupae (B. mori), (e) Bombay locust (P. succincta), and (f) giant water bug (L. indicus).

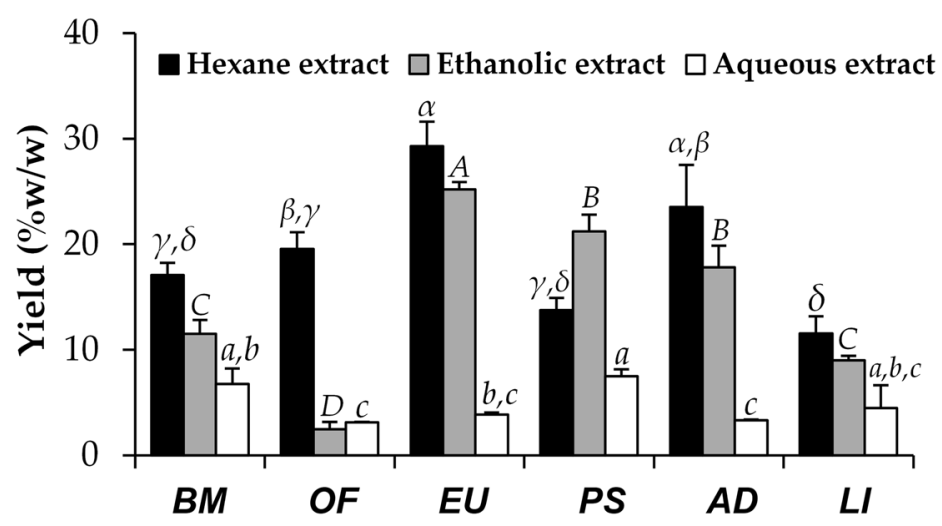

Figure 2. Yields of insect extracts, including B. mori (BM), O. fuscidentalis (OF), Euconocephalus sp. (EU), $P$. succincta (PS), A. domesticus (AD), and L. indicus (LI). The data are expressed as mean $\pm \mathrm{SD}(\mathrm{n}=3)$. The Greek alphabet letters $(\alpha, \beta, \gamma$, and $\delta)$ indicate significant differences among hexane extracts, the capital letters $(A, B, C$, and $D$ ) indicate significant differences among ethanolic extracts, and the small case letters $(a, b$, and $c)$ indicate significant differences among aqueous extracts. The data were analyzed using One-Way ANOVA followed by post hoc Tukey test $(p<0.05)$.

Although there have been several studies about Thai edible insects, most of them were related to their nutritional constituents. The biological activities of Thai edible insects, including antioxidant and anti-aging activities, have not been reported. This study would be the first to present antioxidant and anti-aging activities of Thai edible insect extracts, including B. mori, O. fuscidentalis, Euconocephalus sp., P. succincta, A. domesticus, and L. indicus. Additionally, the irritation properties were also firstly investigated in the present study to confirm their safety for topical application.

\section{Results and discussion}

Insect extracts. Thai edible insects (Fig. 1) were extracted and yield of each extract is shown in Fig. 2. Hexane extracts of most insects, except for P. succincta, provided the highest yield, followed by ethanolic extracts, and aqueous extracts, respectively. The reason might be due to a high amount of fat content of insects. Since these fat components are hydrophobic, they could be extracted well using nonpolar solvent, e.g. hexane. Semi-polar solvent like ethanol could also be used to extract hydrophobic compounds but with less extraction efficacy ${ }^{5}$. Several previous studies reported that fat was abundant in biomass of insects, ranging from 4.2 to $77.2 \%$, which was accounted for about $26.8 \%$ on average dried insects ${ }^{6,7}$.

Among several insect extracts, Euconocephalus sp. yielded the significantly highest extract content when extracted by hexane $(29.3 \pm 2.3 \% \mathrm{w} / \mathrm{w})(p<0.05)$, followed by A. domesticus $(23.5 \pm 4.0 \% \mathrm{w} / \mathrm{w})$, O. fuscidentalis $(19.6 \pm 1.6 \% \mathrm{w} / \mathrm{w})$, B. mori $(17.1 \pm 1.2 \% \mathrm{w} / \mathrm{w})$, P. succincta $(13.8 \pm 1.2 \% \mathrm{w} / \mathrm{w})$, and L. indicus $(11.5 \pm 1.7 \% \mathrm{w} / \mathrm{w})$, respectively. Similarly, Euconocephalus sp. yielded the significantly highest extract content when extracted by ethanol $(25.2 \pm 0.7 \% \mathrm{w} / \mathrm{w})(p<0.05)$, but followed by P. succincta $(21.2 \pm 1.6 \% \mathrm{w} / \mathrm{w})$, A. domesticus $(17.8 \pm 2.0 \%$ $\mathrm{w} / \mathrm{w}), B$. mori $(11.5 \pm 1.3 \% \mathrm{w} / \mathrm{w})$, L. indicus $(9.0 \pm 0.5 \% \mathrm{w} / \mathrm{w})$, and O. fuscidentalis $(2.5 \pm 0.7 \% \mathrm{w} / \mathrm{w})$, respectively. The reason might be due to high fat content in the hexane and ethanolic extracts of Euconocephalus sp. The previous studies reported that fat content of some grasshopper species belonging to Acrididae family was in range of 4.2 to $22.2 \%$ of body weight ${ }^{8}$, whereas fat content of $A$. domesticus was around $10 \%$ of body weight ${ }^{9}$ and $P$. succincta contained a low amount of fat $(\sim 1.5 \% \text { of the body weight })^{7}$.

In contrast, yields of aqueous extracts of all insects, which were extracted by digestion, were the lowest among various solvents. Owing to duration of extraction and numbers of extraction cycles. 


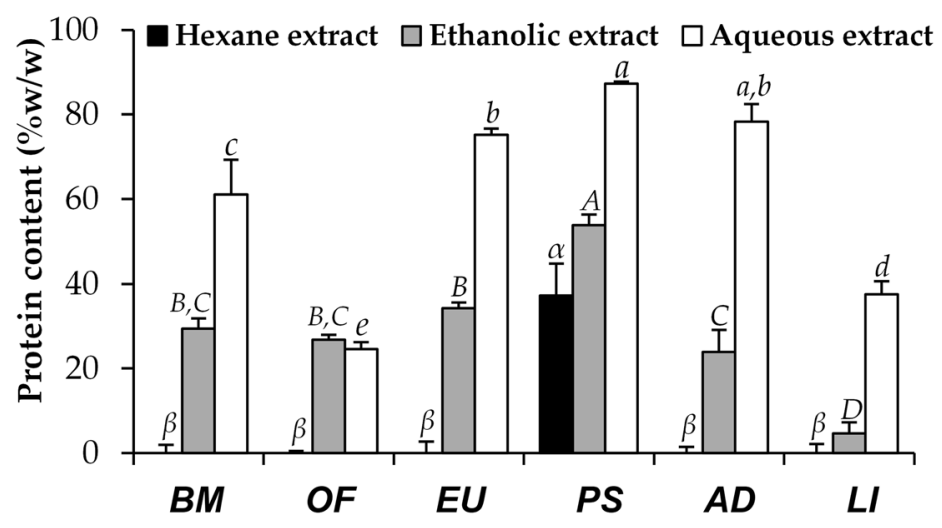

Figure 3. The protein content of Thai edible insect extracts, including B. mori (BM), O. fuscidentalis (OF), Euconocephalus sp. (EU), P. succincta (PS), A. domesticus (AD), and L. indicus (LI). The data are expressed as mean $\pm \mathrm{SD}(\mathrm{n}=3)$. The Greek alphabet letters $(\alpha$ and $\beta)$ indicate significant differences among hexane extracts, the capital letters $(A, B, C$, and $D)$ indicate significant differences among ethanolic extracts, the small case letters $(a, b, c, d$, and $e$ ) indicate significant differences among aqueous extracts. The data were analyzed using OneWay ANOVA followed by post hoc Tukey test $(p<0.05)$.

Protein content of insect extracts. The protein content of each insect extract is shown in Fig. 3. The present study demonstrated that aqueous extracts of most insects contained higher protein content than ethanolic extracts. Additionally, protein was not detected in hexane extracts of most insects. The reason was due to the less extraction efficiency of ethanol to extract protein comparing to DI water since DI water is more hydrophilic. Additionally, some protein might be denatured or precipitated during the extraction process ${ }^{10}$. Similarly, hexane which is non-polar organic solvent could not extract protein well because of its lipophilicity that was incompatible with protein. Apart from protein component, the compositions of hexane extract were nonpolar compounds, e.g. flavonoids, lipids, saturated fatty acids, monounsaturated fatty acids, and polyunsaturated fatty acids $^{11}$. These results corresponded well to a previous study noted that high protein content $(68.8 \pm 0.4 \% \mathrm{w} / \mathrm{w})$ was detected in aqueous extract of Protaetia brevitarsis larvae ${ }^{12}$.

The present study revealed that the protein content of the insects extracted by maceration and digestion ranged from $4.7 \pm 2.6$ to $87.3 \pm 0.5 \% \mathrm{w} / \mathrm{w}$ which were related to a previous study reported that dry basis protein content of the insects ranged from 15 to $81 \%^{7}$. Interestingly, the aqueous, ethanolic, and hexane extracts of $P$. succincta had the significantly highest protein content among several insects, which were $87.3 \pm 0.5,53.8 \pm 2.5$, and $37.2 \pm 7.4 \% \mathrm{w} / \mathrm{w}$, respectively $(p<0.05)$. These findings were in good agreement with a previous study that reported the protein content of defatted locust extract, investigated using the Kjeldahl method, was $82.3 \%$ of dry weight, although the estimated protein content of a sample may be varied depending on the technique applied ${ }^{13}$. Kjeldahl is a method that involves digesting food with a strong acid, which results in the release of nitrogen, which is then measured using a titration approach ${ }^{14}$. Although the Kjeldahl technique is regarded as the worldwide standard and therefore simple to compare findings with other laboratories, it does not measure real protein and can result in overestimation of protein owing to the use of the standard nitrogen correction factor ${ }^{14}$. On the other hand, the BCA technique, which is used in the present study, is based on two chemical reactions, including the biuret reaction, which reduces cupric ions $\left(\mathrm{Cu}^{2+}\right)$ to cuprous ions $\left(\mathrm{Cu}^{1+}\right)$ via peptide bonds and the chelation of one $\mathrm{Cu}^{1+}$ molecule with two BCA molecules to form a bright purple complex which is spectrophotometrically detected $^{15}$. Besides, BCA is simpler, ease of use, takes less time for the experiment, requires fewer instruments, high sensitivity, and tolerance of interfering species, e.g. common surfactants ${ }^{15-17}$. The findings revealed that the protein contents analyzed by BCA in the current investigation were equivalent to those found in the prior study utilizing the Kjeldahl method.

Therefore, protein might be a major component in most insect extracts and was efficiently extracted by water, an environmentally friendly method. However, several previous studies demonstrated that protein content of insects could be affected by different environmental factors, including origin, stage of life, and feeding ${ }^{18}$.

Antioxidant activities of insect extracts. Antioxidant activities of Thai edible insect extracts were determined by 4 different methods, including ABTS, DPPH, FRAP, and FTC assay since multiple reactions and mechanisms are reported which involve antioxidant process. Both ABTS and DPPH assays indicate the abilities of test compound to scavenge free radicals and are expressed as TEAC value and DPPH inhibition percentage, respectively ${ }^{19}$. While FRAP assay represents antioxidant potential of test sample through the reduction of ferric iron $\left(\mathrm{Fe}^{3+}\right)$ to ferrous iron $\left(\mathrm{Fe}^{2+}\right)$, which is expressed as $\mathrm{EC}_{1}$ value. Additionally, FTC assay is the most studied biologically relevant free radical chain reaction that indicates a protective effect on lipid peroxidation of test compound ${ }^{20}$. Therefore, these methods were used to confirm the antioxidant activities of insect extracts.

The antioxidant activity of each insect extract is shown in Fig. 4. The hydrophilicity of extracted solvent tended to affect the antioxidant activities since both aqueous and ethanolic extracts possessed dominant antioxidant activities in ABTS, DPPH, and FRAP assay, whereas hexane extracts possessed dominant inhibitory 

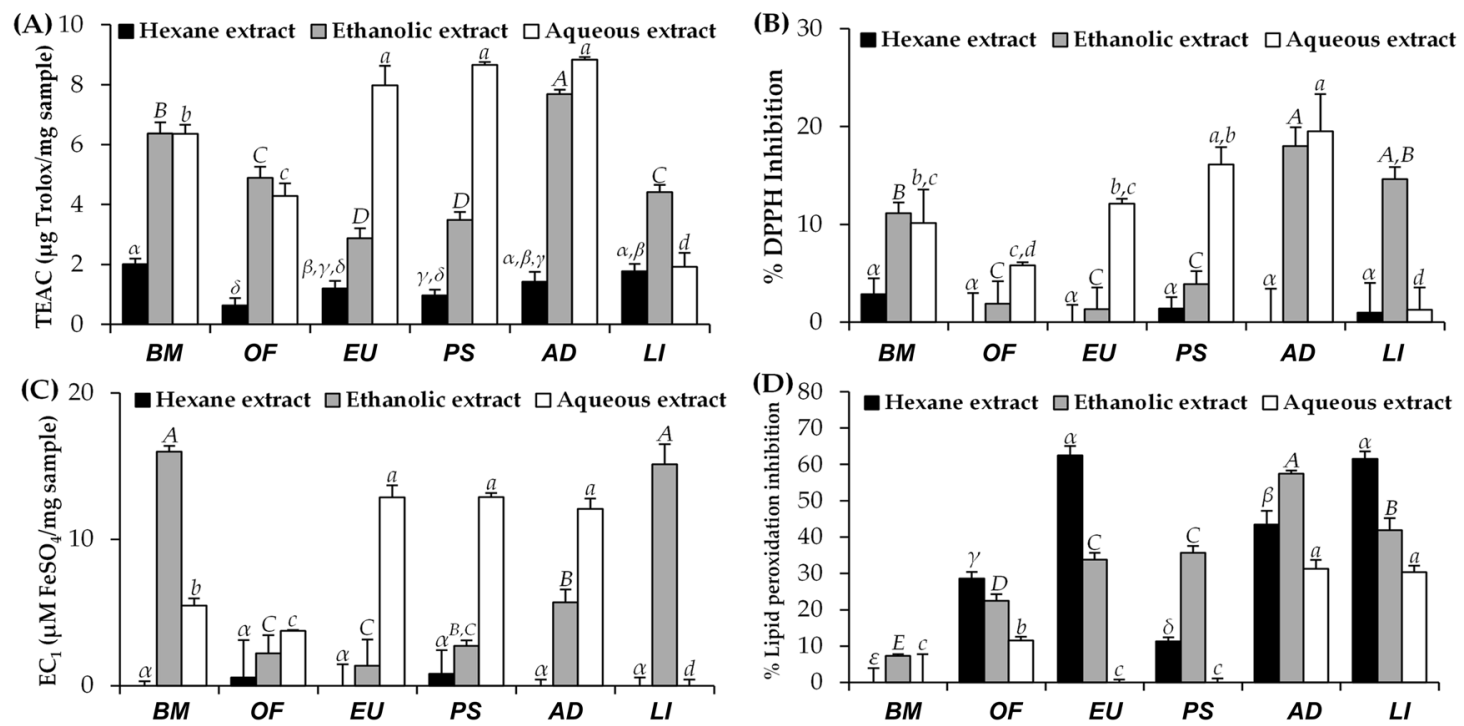

Figure 4. Antioxidant activities of Thai edible insect extracts, including B. mori (BM), O. fuscidentalis (OF), Euconocephalus sp. (EU), P. succincta (PS), A. domesticus (AD), and L. indicus (LI) investigated by ABTS assay (A), DPPH assay (B), FRAP assay $(\mathbf{C})$, and FTC assay $(\mathbf{D})$. The data are expressed as mean $\pm \mathrm{SD}(\mathrm{n}=3)$. The Greek alphabet letters $(\alpha, \beta, \gamma, \delta$, and $\varepsilon)$ indicate significant differences among hexane extracts, the capital letters $(A, B, C, D$, and $E)$ indicate significant differences among ethanolic extracts, the small case letters $(a, b, c$, and $d$ ) indicate significant differences among aqueous extracts. The data were analyzed using One-Way ANOVA followed by post hoc Tukey test $(p<0.05)$.

activity against lipid peroxidation in FTC assay. The likely explanation might be due to the compatibility of test compounds with test systems ${ }^{21}$. Interestingly, the aqueous extracts, which were obtained from digestion for only $3 \mathrm{~h}$, tended to possess higher antioxidant activities than the ethanolic extracts. The likely explanation might be due to higher hydrophilic property of aqueous $(\varepsilon=78.4)$ comparing to ethanol $(\varepsilon=24.5)^{22}$. Additionally, higher temperature used in digestion process could be another factor leading to higher extraction efficiency of aqueous. Therefore, the aqueous extracts of most insects possessed the highest scavenging activities on $\mathrm{ABTS}^{+}$and $\mathrm{DPPH}$, as well as ferric reducing abilities comparing to other solvents. However, B. mori and L. indicus ethanolic extracts possessed the dramatically highest ferric reducing abilities. This could be explained by various bioactive compounds which have been previous detected in B. mori and L. indicus, e.g. alkaloids, phenolic, and flavonoid compounds, which could be extracted well by ethanol ${ }^{21,23}$.

Among various insect extracts, $A$. domesticus and P. succincta aqueous extracts were predominant as radical scavenger and reductant with the significantly highest TEAC values of $8.8 \pm 0.1$ and $8.7 \pm 0.1 \mu \mathrm{g}$ Trolox $/ \mathrm{mg}$ sample, DPPH' scavenging activities of $19.5 \pm 3.8 \%$ and $16.1 \pm 1.8 \%$, and $\mathrm{EC}_{1}$ values of $12.1 \pm 0.7$ and $12.9 \pm 0.3 \mu \mathrm{M} \mathrm{FeSO}_{4} /$ mg sample, respectively $(p<0.05)$. These findings were in good accordance with a previous study reported that Gryllodes sigillatus, which is one of cricket species, possessed the highest $\mathrm{ABTS}^{+}$and DPPH scavenging activities among several insects ${ }^{24}$. Additionally, these results corresponded well to a previous study reported that the aqueous extracts of some grasshopper species and $A$. domesticus possessed the potent ferric reducing abilities with $\mathrm{EC}_{1}$ values of $2.1 \pm 0.2$ and $1.8 \pm 0.1 \mathrm{mmol} \mathrm{Fe}^{2+} / 100 \mathrm{~g}$ sample ${ }^{25}$. Thus, the mechanisms of aqueous insect extracts on oxidation inhibition were various, including radical scavenging activities and ferric reducing abilities.

Apart from A. domesticus and P. succincta aqueous extracts, the significantly highest ferric reducing abilities were also detected in ethanolic extract of $B$. mori and $L$. indicus, with $\mathrm{EC}_{1}$ values of $16.0 \pm 0.4$ and $15.1 \pm 1.4 \mu \mathrm{M}$ $\mathrm{FeSO}_{4} / \mathrm{mg}$ sample, respectively $(p<0.05)$. The likely explanation might be due to several antioxidant compounds, e.g. quercetin-3,4,-O-diglucoside, phenolics, flavonoids, and riboflavin (vitamin B2), which have been detected in B. mori and L. indicus ${ }^{26}$. Since B. mori was normally fed with mulberry leaves, quercetin-3,4,-O-glucoside, a derivative of quercetin with two beta-D-glucosyl residues attached at positions $3^{\prime}$ and $4^{\prime}$ which is rich in mulberry leaves, was also detected in B. mori ${ }^{27}$. According to a potent ferric reducing ability of quercetin-3,4,-O-glucoside ${ }^{28}$, B. mori ethanolic extract also exhibited strong ferric reducing ability.

On the other hand, the results of lipid peroxidation inhibitory activities showed a different trend in comparison to the other methods. The hexane extract of Euconocephalus sp. and L. indicus had the significantly highest lipid peroxidation inhibitory activities with lipid peroxidation inhibition of $62.5 \pm 2.6 \%$ and $61.6 \pm 2.0 \%$, respectively $(p<0.05)$. The reason would be lipid peroxidation test system was more compatible with hydrophobic test compounds, which were extracted well using non-polar solvent, e.g. hexane ${ }^{29}$.

The correlations between the protein content of aqueous insect extracts and their antioxidant activities from various tests, including ABTS, DPPH, FRAP, FTC assays, are shown in Fig. 5. A strong positive correlation was detected in $\mathrm{ABTS}^{+}$scavenging activities with an $\mathrm{R}^{2}$ of 0.8013 . Additionally, these graphs showed moderate positive correlations between the protein content of aqueous insect extracts and antioxidant activities in DPPH and FRAP assay with $\mathrm{R}^{2}$ of 0.7489 and 0.7961 , respectively. Hence, protein from aqueous insect extracts was a major antioxidant compound that possessed radical scavenging activities and ferric reducing abilities. A previous study suggested that amino acids were found to be efficient antioxidants due to their chelating properties ${ }^{30}$. The amino 

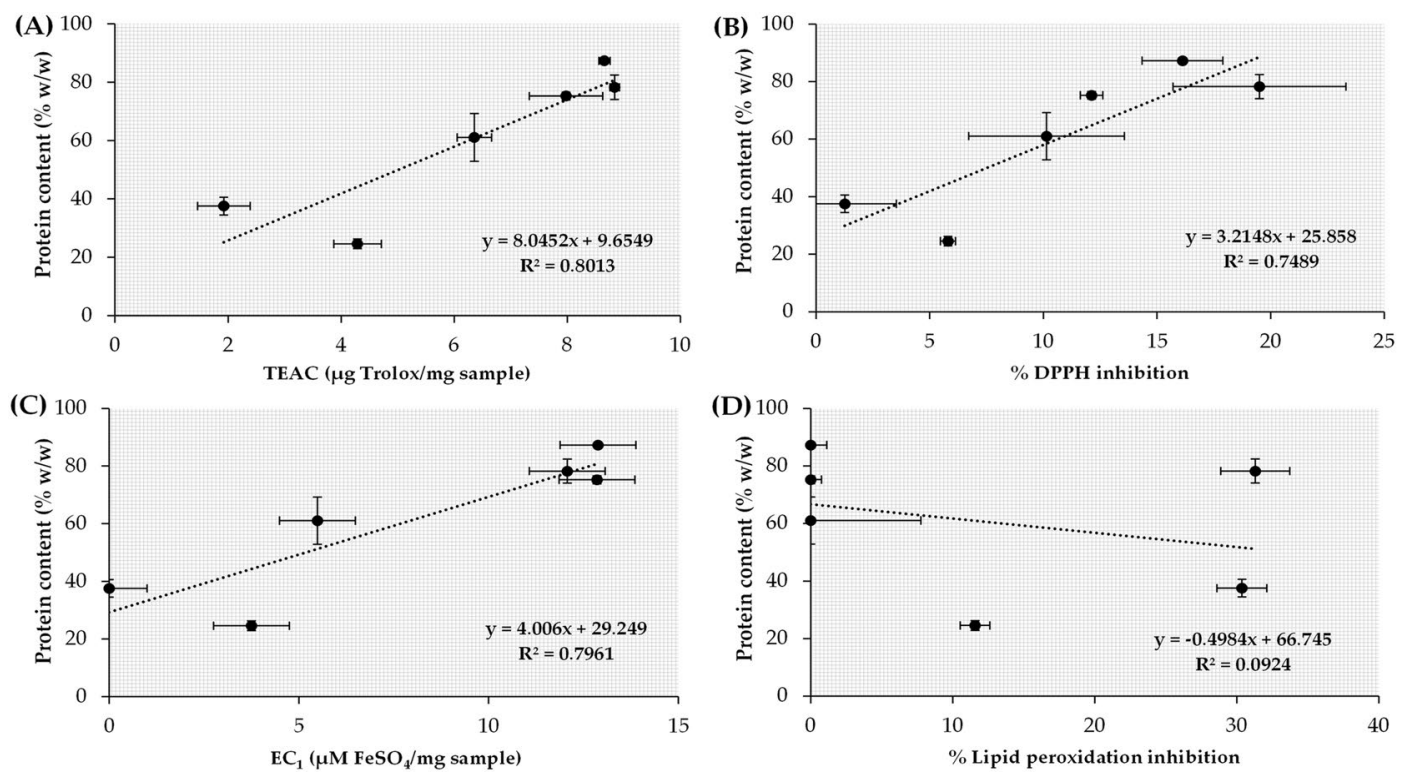

Figure 5. Correlations between protein content and antioxidant activities of aqueous insect extracts, investigated by ABTS assay (A), DPPH assay (B), FRAP assay (C), and FTC assay (D).
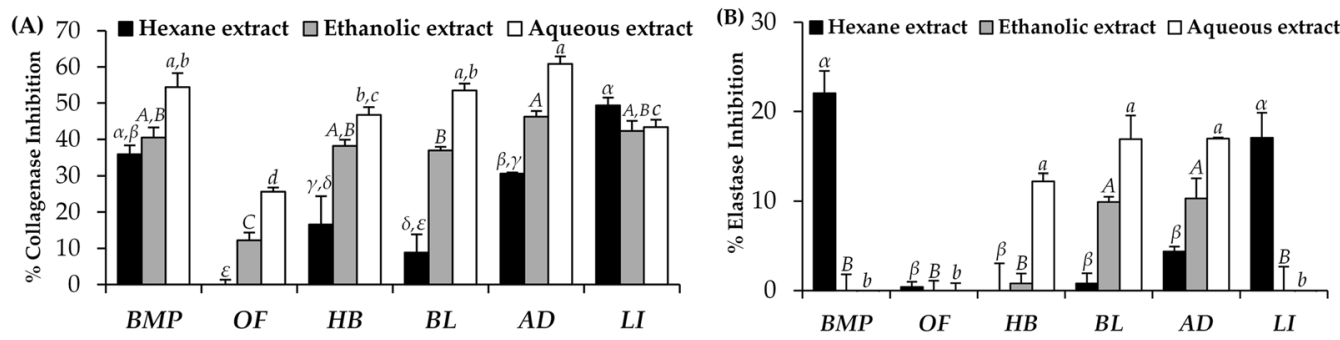

Figure 6. Anti-aging activities of Thai edible insect extracts, including B. mori (BM), O. fuscidentalis (OF), Euconocephalus sp. (EU), P. succincta (PS), A. domesticus (AD), and L. indicus (LI)investigated by collagenase inhibitory determination (A) and elastase inhibitory determination (B). The data are expressed as mean \pm SD $(\mathrm{n}=3)$. The Greek alphabet letters $(\alpha, \beta, \gamma, \delta$, and $\varepsilon)$ indicate significant differences among hexane extracts, the capital letters $(A, B$, and $C)$ indicate significant differences among ethanolic extracts, the small case letters $(a$, $b, c$, and $d$ ) indicate significant differences among aqueous extracts. The data were analyzed using One-Way ANOVA followed by post hoc Tukey test $(p<0.05)$.

acids had an ability to convert hydroperoxides into imines and sulfur-containing amino acids and could reduce hydroperoxides into the respective inactive hydroxylic derivatives ${ }^{30}$.

In contrast, there was no relationship between the protein content and inhibitory activities against lipid peroxidation $\left(\mathrm{R}^{2}=0.0924\right)$. The explanation might be due to the incompatibility of protein with the lipid peroxidation inhibition test system since most of protein was hydrophilic and soluble well in polar solvent. Therefore, hexane insect extracts might contain some other bioactive compounds, which owning lipid peroxidation inhibitory activity, e.g. flavonoid, lipids, saturated fatty acids, monounsaturated fatty acids, and polyunsaturated fatty acids ${ }^{11}$.

Anti-aging activities of insect extracts. Collagen and elastin are predominant extracellular matrix components presented in dermal layer of human skin ${ }^{31}$. Collagen fibers, which are produced by fibroblasts, are responsible for tensile strength and toughness of skin. These fibers can be degraded by matrix metalloproteinase-1 (MMP-1), also known as collagenase, and resulting in skin aging ${ }^{32}$. Additionally, elastin fibers comprising about $5 \%$ of the dermis layer provide elasticity and resilience of skin. The cleavage of elastin fibers by elastase leads to sagging and wrinkling skin ${ }^{19,32}$. Therefore, the bioactive compounds with anti-collagenase and antielastase properties could delay skin aging process.

The anti-aging activity of each insect extract is shown in Fig. 6. Among various solvents, aqueous extracts of most insects possessed the highest anti-collagenase activities, followed by ethanolic extracts, and hexane extracts, respectively. Interestingly, the aqueous extract of $A$. domesticus, $B$. mori, and $P$. succincta possessed the significantly highest anti-collagenase activities with the collagenase inhibition of $60.8 \pm 2.1 \%, 54.4 \pm 3.9 \%$, and $53.5 \pm 1.9 \%$, respectively $(p<0.05)$. These findings supported a previous study reported that the extract of Gryllus 


\begin{tabular}{|l|c|l|}
\hline Sample & IS & Irritation level \\
\hline Positive control $(1 \% \mathrm{w} / \mathrm{v}$ SLS) & $10.0 \pm 0.5$ & Severe irritation \\
\hline Negative control $(0.9 \% \mathrm{w} / \mathrm{v} \mathrm{NaCl})$ & $0.0 \pm 0.0$ & No irritation \\
\hline Vehicle $(0.05 \% \mathrm{w} / \mathrm{v} \mathrm{DMSO})$ & $0.0 \pm 0.0$ & No irritation \\
\hline Vehicle (DI water) & $0.0 \pm 0.0$ & No irritation \\
\hline
\end{tabular}

Table 1. Irritation score (IS) and irritation levels from HET-CAM assay $(n=3)$.

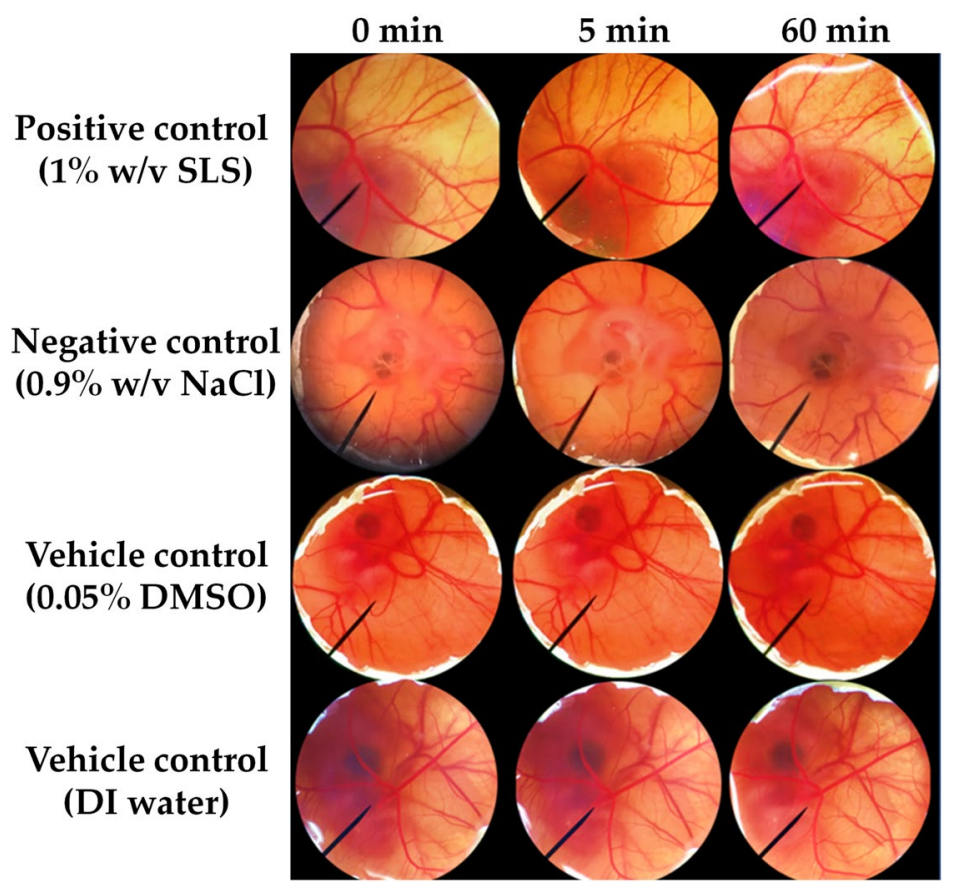

Figure 7. Effect of $1 \% \mathrm{w} / \mathrm{v}$ SLS (positive control), $0.9 \% \mathrm{w} / \mathrm{v} \mathrm{NaCl}$ solution, $0.05 \% \mathrm{DMSO}$ (vehicle control), and DI water (vehicle control) on chorioallantoic membrane before exposure $(0 \mathrm{~min})$, after $5 \mathrm{~min}$, and $60 \mathrm{~min}$ exposure.

bimaculatus De Geer, which is one of cricket species in Gryllidae family, had a protective effect against wrinkle formation via collagen degradation inhibition ${ }^{33}$.

Besides, the significantly highest elastase inhibitory activities were found in the aqueous extract of $A$. domesticus $(17.0 \pm 0.1 \%)$, P. succincta (16.9 $\pm 2.7 \%)$, and Euconocephalus sp. $(12.2 \pm 0.9 \%)$, as well as hexane extracts of $B$. mori $(22.1 \pm 2.5 \%)$ and $L$. indicus $(17.1 \pm 2.8 \%)(p<0.05)$. These results were in good accordance with a previous study reported that $A$. domesticus possessed strong pancreatic elastase inhibitory activity ${ }^{34}$.

Irritation properties of insect extracts. The irritation properties of Thai edible insect extracts were investigated using HET-CAM assay which had been verified for reliability. In the present study, no irritation sign on CAM was induced by a negative control $(0.9 \% \mathrm{w} / \mathrm{v} \mathrm{NaCl}$ solution) and vehicle controls (DI water and $0.05 \% \mathrm{w} / \mathrm{v}$ DMSO).

In contrast, severe irritation signs on the CAM were detected in a positive control ( $1 \% \mathrm{w} / \mathrm{v}$ SLS) with IS score of $10.0 \pm 0.5$ (Table 1). All signs of irritation, including hemorrhage, coagulation, and vascular lysis were detected on the CAM exposed to $1 \% \mathrm{w} / \mathrm{v}$ SLS within $5 \mathrm{~min}$ and more pronounced after $60 \mathrm{~min}$ as shown in Fig. 7.

All insect extracts in the present study were safe since they induced no irritation on CAM, except for $P$. succincta. Ethanolic and hexane extracts of $P$. succincta induced moderate irritation with IS of $6.2 \pm 0.5$ and $7.4 \pm 0.4$, respectively. All irritation signs were detected on the CAM after exposed to $P$. succincta hexane extract, whereas only vascular lysis and hemorrhage were detected on the CAM after exposed to the P. succincta ethanolic extract as shown in Fig. 8. The results were related well to a previous study reported that $P$. succincta could trigger hypersensitivity reaction and $P$. succincta was identified as a cross-reacting allergen with crustaceans ${ }^{35}$. Therefore, the hexane and ethanolic extracts of $P$. succincta might be noted as a skin irritant and had a precaution for using topically on human skin.

Since HET-CAM assay was usually employed as an alternative irritation test for human tissue, including eye and/or skin irritation ${ }^{36}$. Extracts from B. mori, O. fuscidentalis, Euconocephalus sp., A. domesticus, and L. indicus were suggested as safe for using topically on human skin. 


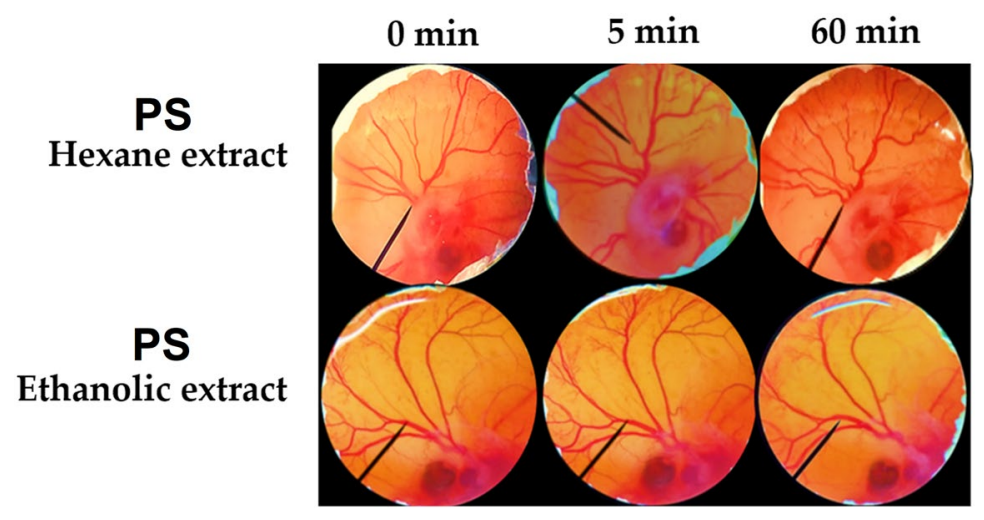

Figure 8. Effect of hexane and ethanolic extracts of $P$. succincta (PS) on chorioallantoic membrane before exposure $(0 \mathrm{~min})$, after $5 \mathrm{~min}$, and $60 \mathrm{~min}$ exposure.

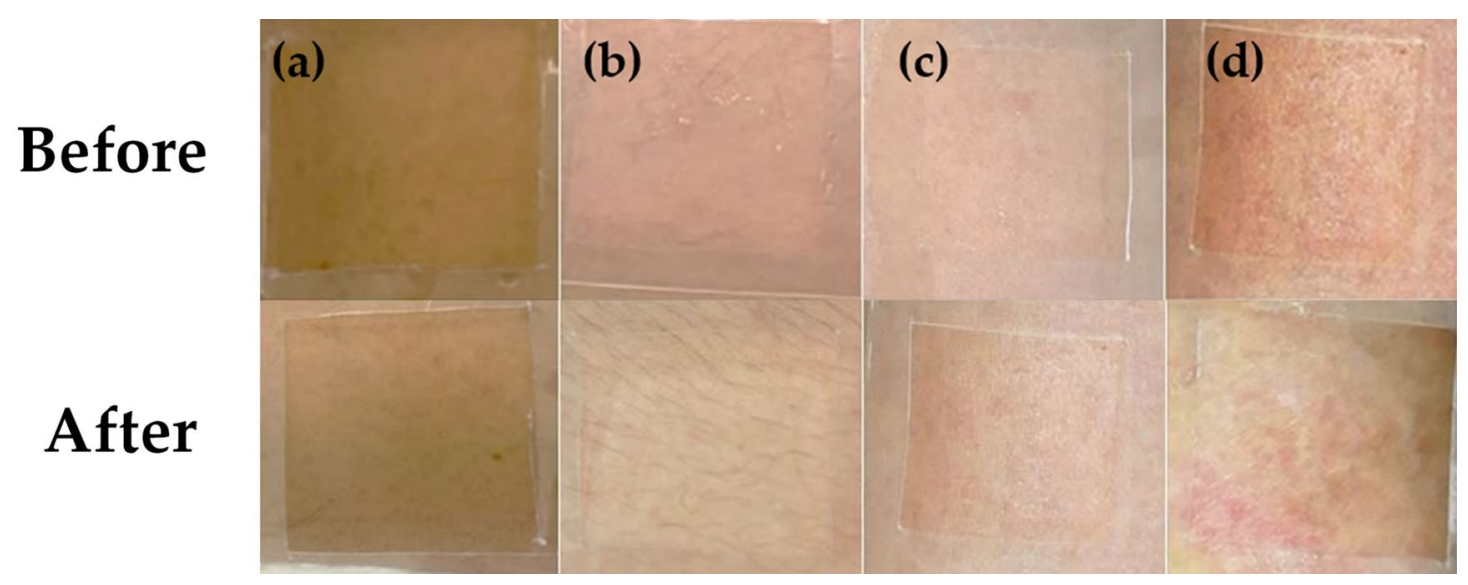

Figure 9. Effect of Thai edible insect extracts on human skin before application (above) and after application (below), including aqueous extract of $B$. mori (BM) (a), aqueous extract of $L$. indicus (LI) (b), hexane extract of L. indicus (LI) (c), and ethanolic extract of B. mori (BM) (d).

Skin irritation effects of insect extracts on human volunteers. The irritation effects of Thai edible insect extracts on human skin are shown in Fig. 9. Since the ethanolic and hexane extracts of $P$. succincta induced irritation signs in HET-CAM test, they were excluded from a clinical study in humans. Among various insects, B. mori and L. indicus extracts induced skin irritation in humans. The aqueous extracts of $B$. mori and L. indicus induced itching in 2 among 30 individual volunteers. Additionally, hexane extract of $L$. indicus induced mild erythema, whereas ethanolic extract of B. mori showed severe signs of skin irritation, including papules and itching. However, there were no signs of edema, vesicles, bullae, or weeping in any volunteer. These results related well with a previous study reported that tropomyosin, which was a dimeric coiled-coil protein for muscle regulation, might contribute significantly to B. mori allergy. Furthermore, B. mori has been reported to be one of a strong IgE cross-reactivity with crustacean ${ }^{37}$. Additionally, a previous study also reported that $L$. indicus appeared to be the insect that was most likely to cause an allergic reaction ${ }^{38}$. Nonetheless, there have not been identified allergen of $L$. indicus in previous studies. Thus, the extracts of B. mori and L. indicus, which caused irritation in human volunteers, should avoid for further topical applications.

In conclusion, there was a significant difference among different insect species (Wilks' lambda $=0.000, \mathrm{~F}$ $(45,128.3)=350.975, p=0.000)$ and extraction method (Wilks' lambda $=0.000, \mathrm{~F}(18,56)=1164.921, p=0.000)$. Aqueous extracts of $A$. domesticus exhibited the significantly highest antioxidant, anti-collagenase, and antielastase activities without irritation in both HET-CAM and clinical studies. As a result, A. domesticus was proposed for further usage as a cosmeceutical active ingredient for anti-wrinkle skin care. However, it was advised that the chemicals responsible for these biological activities should be further identified. Although utilizing the entire body of the insect would facilitate scale-up production in future applications, further independently investigation for each part of the insect, such as the head, thorax, and abdomen of A. domesticus would be suggested. The current study's findings would lead to the selection of an appealing insect family for further intensive comparative research. 


\section{Materials and methods}

Insect material. Frozen B. mori, O. fuscidentalis, Euconocephalus sp., P. succincta, A. domesticus, and L. indicus were purchased from a local market in Chiang Mai, Thailand during October 2020. Each Thai edible insects were identified by Mr. Pattarawich Dawwrueng, an entomologist at Department of Entomology, Faculty of Agriculture, Kasetsart University. The frozen insects were defrosted overnight at room temperature and dried using a hot air oven at $45{ }^{\circ} \mathrm{C}$ until constant weights were obtained. The dried insects were then grounded into fine powders using a Moulinex ${ }^{\circledR}$ blender, model number LM2070BD (Moulinex SA, Bagnolet, France) and kept in a desiccator until further use.

Chemical reagents. Acetic acid, 2,2'-azinobis (3-ethylbenzothiazoline-6-sulfonic acid) diammonium salt (ABTS), 2,2-diphenyl-1-picrylhydrazyl radical (DPPH), 2, 4, 6 tripyridyl-s-triazine (TPTZ), 6-hydroxy-2,5,7,8tetramethylchroman-2-carboxylic acid (Trolox), gallic acid, linoleic acid, and hydrochloric acid ( $\mathrm{HCl}$ ) were purchased from Sigma Aldrich (St. Louis, MO, USA). Collagenase from Clostridium histolyticum, N-[3-(2-furyl) acryloyl]-Leu-Gly-Pro-Ala (FALGPA), elastase from porcine pancreas, N-succinyl-Ala-Ala-Ala-p-nitroanilide (AAAVPN), disodium hydrogen phosphate $\left(\mathrm{Na}_{2} \mathrm{HPO}_{4}\right)$, potassium dihydrogen phosphate $\left(\mathrm{KH}_{2} \mathrm{PO}_{4}\right)$, potassium persulfate $\left(\mathrm{K}_{2} \mathrm{~S}_{2} \mathrm{O}_{8}\right)$, potassium chloride $(\mathrm{KCl})$, sodium carbonate $\left(\mathrm{Na}_{2} \mathrm{CO}_{3}\right)$, sodium chloride $(\mathrm{NaCl})$, ferric chloride $\left(\mathrm{FeCl}_{3}\right)$, ferrous sulfate $\left(\mathrm{FeSO}_{4}\right)$, ferrous chloride $\left(\mathrm{FeCl}_{2}\right)$, and ammonium thiocyanate $\left(\mathrm{NH}_{4} \mathrm{SCN}\right)$ were purchased from Fisher Chemicals (Loughborough, UK). Bovine serum albumin was purchased from Merck (Darmstadt, Germany). Tricine and tris base were purchased from Bio-Rad Laboratories (Richmond, CA, USA). Sodium acetate trihydrate $\left(\mathrm{CH}_{3} \mathrm{COONa} \cdot 3 \mathrm{H} 2 \mathrm{O}\right)$, sodium hydroxide $(\mathrm{NaOH})$, dimethyl sulfoxide (DMSO), and ethanol were analytical grade and purchased from RCI Labscan Co., Ltd. (Bangkok, Thailand).

Preparation of insect extract. Maceration. The dried powders of insects were macerated using hexane or $95 \%$ ethanol with the weight ratio of insect powder to solvent of 1:5 at room temperature for $24 \mathrm{~h}$ for 3 cycles. After maceration, the solvents were removed under vacuum at $50{ }^{\circ} \mathrm{C}$ using a rotary evaporator (Eyela, Tokyo, Japan) until constant weights were attained. The insect extracts were kept at $4{ }^{\circ} \mathrm{C}$ until further use.

Digestion. The dried powders of insects were digested using DI water with the weight ratio of insect powder to solvent of $1: 3$ at $45^{\circ} \mathrm{C}$ for $3 \mathrm{~h}$. After digestion, the solvent was eliminated using a freeze dryer (FreeZone 4.5 model 7,750,031, Labconco, Kansas, MO, USA) until constant weights were attained. The insect extracts were kept at $4^{\circ} \mathrm{C}$ until further use.

Determination of protein content of insect extracts. The protein content of insect extracts was investigated using bicinchoninic acid (BCA) assay ${ }^{39}$. Briefly, BCA solution was prepared by mixing sodium carbonate, sodium bicarbonate, bicinchoninic acid, and sodium tartrate in $0.1 \mathrm{M}$ sodium hydroxide solution (final $\mathrm{pH} 11.25$ ) with $4 \% \mathrm{w} / \mathrm{v}$ aqueous cupric sulfate solution. Then $25 \mu \mathrm{l}$ of each insect extract solution was mixed with $200 \mu \mathrm{l}$ of BCA solution and incubated at $37^{\circ} \mathrm{C}$ for $2 \mathrm{~h}$. The intense purple color formed by the above reaction was then measured at $562 \mathrm{~nm}$ using a multimode detector (BMG Labtech, Ortenberg, Germany). The protein content of each sample was determined by comparison with protein standard of BSA. The results were reported as percentages of protein content comparing to the weight of each extract.

Determination of antioxidant activities of insect extracts. 2,2-azinobis (3-ethylbenzothiazoline-6-sulphonic acid) (ABTS) assay. The free radical scavenging activities against ABTS radical cations $\left(\mathrm{ABTS}^{+}\right)$of insect extracts were investigated using ABTS assay ${ }^{40,41}$. Briefly, ABTS ${ }^{+}$solution was prepared by mixing $7 \mathrm{mM}$ ABTS solution and $2.45 \mathrm{mM} \mathrm{K}_{2} \mathrm{~S}_{2} \mathrm{O}_{8}$ solution in a volume ratio of 2:3. The mixture was kept in a dark place for $16 \mathrm{~h}$. The $\mathrm{ABTS}^{+}$solution was then diluted with 20 -fold excess of ethanol to obtain an absorbance of $0.7 \pm 0.1$ units at $750 \mathrm{~nm}$. Consequently, $20 \mu \mathrm{l}$ of $1 \mathrm{mg} / \mathrm{ml}$ of each insect extract solution was mixed with $180 \mu \mathrm{l}$ of $\mathrm{ABTS}^{+}$solution and incubated at room temperature for $5 \mathrm{~min}$. Then the mixture was measured for an absorbance at $750 \mathrm{~nm}$ using a multimode detector (BMG Labtech, Ortenberg, Germany). The free radical scavenging activity was reported as Trolox equivalent antioxidant capacity (TEAC) which represents the amount of Trolox that is equivalent to $1 \mathrm{mg}$ of each insect extract. The experiments were performed in triplicate.

2,2-diphenyl-1-picrylhydrazyl (DPPH) assay. The free radical scavenging activities against DPPH radical $(\mathrm{DPPH})$ of insect extracts were investigated using DPPH assay ${ }^{41,42}$. Briefly, $20 \mu \mathrm{lof} 1 \mathrm{mg} / \mathrm{ml}$ of each insect extract solution was mixed with $180 \mu \mathrm{l}$ of DPPH solution in methanol. Following incubation in a dark place for $30 \mathrm{~min}$, the mixture was then measured for an absorbance at $520 \mathrm{~nm}$ using a multimode detector (BMG Labtech, Ortenberg, Germany). The scavenging activity was reported as percentage of DPPH' inhibition which was calculated using the following equation: \% Inhibition $=[(\mathrm{A}-\mathrm{B}) / \mathrm{A}] \times 100$, where $\mathrm{A}$ is the absorbance of the mixture solution containing DPPH solution and solvent and B is the absorbance of the mixture solution containing DPPH' solution and insect extracts. Ascorbic acid was used as a positive control. The experiments were performed in triplicate.

Ferric reducing antioxidant power (FRAP) assay. The ferric ion reducing abilities of insect extracts were investigated using FRAP assay ${ }^{41-43}$. Briefly, FRAP solution was prepared by mixing $5 \mathrm{ml}$ of $10 \mathrm{mM}$ TPTZ solution in $40 \mathrm{mM} \mathrm{HCl}$ and $5 \mathrm{ml}$ of $20 \mathrm{mM} \mathrm{FeCl}_{3}$ in $50 \mathrm{ml}$ of $0.3 \mathrm{M}$ acetate buffer (pH 3.6). Consequently, $20 \mu \mathrm{lof} 1 \mathrm{mg} / \mathrm{ml}$ of each insect extract solution was mixed with $180 \mu \mathrm{l}$ of FRAP solution and incubated at room temperature for $5 \mathrm{~min}$. The mixture was then measured for an absorbance at $595 \mathrm{~nm}$ using a multimode detector (BMG Labtech, 
Ortenberg, Germany). Ferrous sulfate $\left(\mathrm{FeSO}_{4}\right)$ was used as a standard. The ferric reducing ability was reported as equivalent concentration value $\left(\mathrm{EC}_{1}\right)$, which represents the amount of $\mathrm{FeSO}_{4}$ that is equivalent to $1 \mathrm{mg}$ of each insect extract. The experiments were performed in triplicate.

Inhibition of lipid peroxidation by ferric thiocyanate (FTC) assay. The lipid peroxidation inhibition activities of insect extracts were investigated by FTC assay with some modifications ${ }^{41-43}$. Briefly, $50 \mu \mathrm{lof} 1 \mathrm{mg} / \mathrm{ml} \mathrm{of} \mathrm{each}$ insect extract solution was mixed with $50 \mu \mathrm{l}$ of $50 \%$ linoleic acid, $50 \mu \mathrm{l}$ of $10 \% \mathrm{NH}_{4} \mathrm{SCN}$ solution, and $50 \mu \mathrm{l}$ of $2 \mathrm{mM} \mathrm{FeCl}_{2}$ solution. The mixture was incubated at $37^{\circ} \mathrm{C}$ for $1 \mathrm{~h}$ and then measured for an absorbance at $500 \mathrm{~nm}$ using a multimode detector (BMG Labtech, Ortenberg, Germany). The result was reported as percentage of lipid peroxidation inhibition which was calculated using the following equation: \% Inhibition $=\{[(C-D)-(A-B)] /$ $(\mathrm{C}-\mathrm{D})\} \times 100$, where $\mathrm{A}$ is an absorbance of the mixture containing insect extract, linoleic acid, $\mathrm{NH}_{4} \mathrm{SCN}$, and $\mathrm{FeCl}_{2}$ solution, $\mathrm{B}$ is an absorbance of the mixture containing insect extract and solvent, $\mathrm{C}$ is an absorbance of the mixture containing linoleic acid, $\mathrm{NH}_{4} \mathrm{SCN}$, and $\mathrm{FeCl}_{2}$ solution, and $\mathrm{D}$ is an absorbance of the mixture containing only solvent. The experiments were performed in triplicate.

Determination of anti-ageing activities of insect extracts. Anti-collagenase activity by spectrophotometric assay. Anti-collagenase activities of insect extracts were investigated by spectrophotometric assay with some modification ${ }^{44}$. The collagenase enzyme activity was deter-mined before performing the experiment and only more than $90 \%$ enzyme activity was used in the experiment. Briefly, $10 \mu \mathrm{lof} 1 \mathrm{mg} / \mathrm{ml}$ of each insect extract solution was mixed with $5 \mathrm{unit} / \mathrm{ml}$ collagenase enzyme and then incubated at room temperature for $15 \mathrm{~min}$. The solution of $2 \mathrm{mM}$ FALGPA solution and tricine buffer ( $\mathrm{pH}$ 7.5) were added, respectively. The mixture was immediately measured for an absorbance at $340 \mathrm{~nm}$ and continuously measured for 20 min using a multimode detector (BMG Labtech, Ortenberg, Germany). The result was reported as percentage of collagenase inhibition which was calculated using the following equation: \% Inhibition $=[1-(\mathrm{A} / \mathrm{B})] \times 100$, where $\mathrm{A}$ is the reaction rate of the mixture containing each insect extract, collagenase enzyme, tricine buffer, and FALGPA solution, and B is the reaction rate of the mixture containing collagenase enzyme, tricine buffer, and FALGPA solution. Oleanolic acid was used as a positive control. The experiments were performed in duplicate.

Anti-elastase activity determination. Anti-elastase activities of insect extracts were investigated by spectrophotometric assay with some modification ${ }^{44}$. The elastase enzyme activity was determined be-fore performing the experiment and only more than $90 \%$ enzyme activity was used in the experiment. Briefly, $10 \mu \mathrm{of} 1 \mathrm{mg} / \mathrm{ml}$ of each insect extract solution was mixed with 4.5 unit/l elastase enzyme and then incubated at room temperature for $15 \mathrm{~min}$. The solution of $1.6 \mathrm{mM} \mathrm{AAAPVN}$ and $0.2 \mathrm{mM}$ Tris- $\mathrm{HCl}$ buffer $(\mathrm{pH} 8.0)$ were added, respectively. The mixture was immediately measured for an absorbance at $410 \mathrm{~nm}$ and continuously measured for $20 \mathrm{~min}$ using a multimode detector (BMG Labtech, Ortenberg, Germany). The result was reported as percentage of elastase inhibition which was calculated using the following equation: $\%$ Inhibition $=[1-(\mathrm{A} / \mathrm{B})] \times 100$, where A is the reaction rate of the mixture containing each insect extract, elastase enzyme, tris $\mathrm{HCl}$ buffer, and AAAVPN solution and $\mathrm{b}$ is the reaction rate of the mixture containing elastase enzyme, tris HCl buffer, and AAAVPN solution. EGCG was used as a positive control. The experiments were performed in duplicate.

Determination of irritation properties by Hen's Egg Test-Chorioallantoic Membrane (HET-CAM) assay. The irritation properties of insect extracts were investigated using HET-CAM assay with some modification ${ }^{45}$. Briefly, the fertilized hen's eggs were incubated in an automatic hatching machine at $37 \pm 0.5^{\circ} \mathrm{C}$ and $55 \pm 7 \%$ of relative humidity for 7 days. Before the investigation, the air chamber was indicated by flooding the light and then the eggshell was opened using an electric drill. Consequently, the white inner membrane, which attached the chorioallantoic membranes (CAM), was moistened with $0.9 \% \mathrm{w} / \mathrm{v} \mathrm{NaCl}$ solution and carefully removed using forceps. After that, $30 \mu \mathrm{l}$ of $1 \mathrm{mg} / \mathrm{ml}$ of each insect extract solution was added to the CAM. The irritation signs, including hemorrhage, vascular lysis, and coagulation, were continuously monitored for 5 min under a stereomicroscope (Olympus, Tokyo, Japan). The solution of SLS (1\% w/v) and normal saline solution $(0.9 \% \mathrm{w} / \mathrm{v} \mathrm{NaCl})$ were used as positive control and negative control, respectively. The irritation property was reported as irritation score which was calculated using the following equation: $\mathrm{IS}=[((301-\mathrm{H})) / 300 \times 5]+[((301$ $-\mathrm{L})) / 300 \times 7]+[((301-\mathrm{C})) / 300 \times 9]$, where $\mathrm{H}$ is the time of vascular hemorrhage observed, $\mathrm{L}$ is the time of vascular lysis observed, and $\mathrm{C}$ is the time of vascular coagulation observed. The IS scores are graded as $0.0-0.9$ indicates no irritation, 1.0-4.9 indicates mild irritation, 5.0-8.9 indicates moderate irritation, and 9.0-21.0 indicates severe irritation. The irritation signs on the CAM were observed again after $60 \mathrm{~min}$ for long term irritation. The experiments were performed in duplicate.

Clinical irritation test using human patch test. Skin irritation induced by insect extracts was investigated by human patch test with some modifications ${ }^{46,47}$. The experiment was approved by the Ethical Review Committee, Faculty of Pharmacy, Chiang Mai University regarding the Declaration of Helsinki. The approved ethical number was $004 / 2018$, which was valid from 06/02/2018 to 05/02/2019. The clinical trial has been reviewed and approved by Thai Clinical Trials Registry (TCTR) Committee on 17/08/2021. The accessible TCTR identification number is TCTR 20210817002 and the valid URL of the registry is https://www.thaiclinicaltri als.org/show/TCTR 20210817002). Thirty healthy volunteers (11 men and 19 women), aged between 21 and 54 years, were included in the study. Informed consent for study participation was obtained from all volunteers. Briefly, $10 \mu \mathrm{l}$ of each insect extract was applied on the forearm of each volunteer in the area of $1.5 \times 1.5 \mathrm{~cm} 2 \mathrm{using}$ a small spatula. The irritation signs were investigated up to $4 \mathrm{~h}$ after application by a qualified person. The skin 
area with no application of insect extract was used as a negative control. Any volunteer exhibiting unequivocal erythema, papule, pustule, or nodule was considered as a positive result ${ }^{43}$.

Statistical analysis. Data were reported as mean \pm standard deviation (S.D.) from three independently performed experiments with three replicates within each experiment. Statistical analysis for the overall significance was carried out using multivariate analysis of variance (MANOVA) and Wilks' Lambda statistics, followed by one-way analysis of variance (ANOVA) and post hoc Tukey's post-hoc test for each dependent variable using SPSS program software version 17. Statistically significant difference was denoted when $p<0.05$.

Received: 19 July 2021; Accepted: 9 November 2021

Published online: 25 November 2021

\section{References}

1. Yen, A. Edible insects: Traditional knowledge or western phobia. Entomol. Res. 39, 289-298. https://doi.org/10.1111/j.1748-5967. 2009.00239.x (2009).

2. Srinroch, C., Srisomsap, C., Chokchaichamnankit, D., Punyarit, P. \& Phiriyangkul, P. Identification of novel allergen in edible insect, Gryllus bimaculatus and its cross-reactivity with Macrobrachium spp. allergens. Food Chem. 184, 160-166. https://doi.org/ 10.1016/j.foodchem.2015.03.094) (2015).

3. Melo, V., Garcia, M., Sandoval, H., Jiménez, H. D. \& Calvo, C. Quality proteins from edible indigenous insect food of Latin America and Asia. Emir. J. Food Agric. 23, 283-289 (2011).

4. Yhoung-aree, J. Edible insects in Thailand: Nutritional values and health concerns. Forest insects as food: Humans bite back, Proceedings of a workshop on Asia-Pacific resources and their potential for development, Thailand, 19-21 February 2008; Patrick B. D., Dennis V. J., Robin N. L., Kenichi S. FAO regional office for Asia and the Pacific: Bangkok, Thailand. (2010)

5. Laroche, M. et al. Comparison of conventional and sustainable lipid extraction methods for the production of oil and protein isolate from edible insect meal. Foods. 8, 572. https://doi.org/10.3390/foods8110572 (2019).

6. Belluco, S. et al. Edible insects in a food safety and nutritional perspective: A critical review. Compr. Rev. Food Sci. Food Saf. 12, 296-313. https://doi.org/10.1111/1541-4337.12014 (2013).

7. Ramos-Elorduy, J. et al. Nutritional value of edible insects from the state of Oaxaca, Mexico. J. Food Compos. Anal. 10, $142-157$. https://doi.org/10.1006/jfca.1997.0530 (1997).

8. Paul, A. et al. Grasshoppers as a food source? A review. Biotechnol. Agron. Soc. 20, 337-352. https://doi.org/10.25518/1780-4507. 12974 (2016).

9. Udomsil, N., Imsoonthornruksa, S., Gosalawit, C. \& Ketudat-Cairns, M. Nutritional values and functional properties of house cricket (Acheta domesticus) and field cricket (Gryllus bimaculatus). Food Sci. Technol. Res. 25, 597-605. https://doi.org/10.3136/ fstr.25.597 (2019).

10. Hiroki, Y., Atsushi, H., Tsutomu, A. \& Kentaro, S. Mechanistic insights into protein precipitation by alcohol. Int. J. Biol. Macromol. 50, 865-887. https://doi.org/10.1016/j.ijbiomac.2011.11.005 (2012).

11. Ramos-Bueno, R. P., González-Fernández, M. J., Sánchez-Muros-Lozano, M. J., García-Barroso, F. \& Guil-Guerrero, J. L. Fatty acid profiles and cholesterol content of seven insect species assessed by several extraction systems. Eur. Food Res. Technol. 242, 1471-1477. https://doi.org/10.1007/s00217-016-2647-7 (2016).

12. Kim, T. K. et al. Effects of organic solvent on functional properties of defatted proteins extracted from Protaetia brevitarsis larvae. Food Chem. 336, 127679. https://doi.org/10.1016/j.foodchem.2020.127679 (2020).

13. Clarkson, C., Mirosa, M. \& Birch, J. Potential of extracted Locusta Migratoria protein fractions as value-added ingredients. Insects. 9, 20. https://doi.org/10.3390/insects9010020 (2018).

14. Hayes, M. Measuring protein content in food: An overview of methods. Foods 9(10), 1340. https://doi.org/10.3390/foods9101340 (2020).

15. Clerici, M., Nelemans, L. C., Buzgo, M. \& Simaite, A. Pitfalls of accurate protein determination inside PLGA nanoparticles using the micro BCA assay. MDPI Proc. 78(1), 28. https://doi.org/10.3390/IECP2020-08671 (2020).

16. Huang, T., Long, M. \& Huo, B. Competitive binding to cuprous ions of protein and BCA in the bicinchoninic acid protein assay. Open Biomed. Eng. 4, 271. https://doi.org/10.2174/1874120701004010271 (2010).

17. Rogatsky, E. Pandora box of BCA assay. Investigation of the accuracy and linearity of the microplate bicinchoninic protein assay: Analytical challenges and method modifications to minimize systematic errors. Anal. Biochem. 631, 114321. https://doi.org/10. 1016/j.ab.2021.114321 (2021).

18. Liu, S. et al. Antioxidant activity and phenolic compounds of Holotrichia parallela Motschulsky extracts. Food Chem. 134, 18851891. https://doi.org/10.1016/j.foodchem.2012.03.091 (2012).

19. Chaiyana, W. et al. Ocimum sanctum Linn. as a natural source of skin anti-ageing compounds. Ind. Crops. Prod. 127, 217-224. https://doi.org/10.1016/j.indcrop.2018.10.081 (2019).

20. Chaiyana, W., Phongpradist, R. \& Leelapornpisid, P. Characterization of hydrodistillated pomelo peel oil and the enhancement of biological activities using microemulsion formulations. Int. J. Pharm. Pharm. Sci. 6, 596-602 (2014).

21. Shantibala, T., Lokeshwari, R. K. \& Debaraj, H. Nutritional and antinutritional composition of the five species of aquatic edible insects consumed in Manipur, India. J. Insect Sci. 14, 14. https://doi.org/10.1093/jis/14.1.14 (2014).

22. Fernandez, D. P., Mulev, Y., Goodwin, A. R. H. \& Sengers, J. L. A database for the static dielectric constant of water and steam. J. Phys. Chem. Ref. Data. 24, 33-70. https://doi.org/10.1063/1.555977 (1995).

23. Rattana, S., Katisart, T., Butiman, C. \& Sungthong, B. Total flavonoids, total phenolics, 1-deoxynojirimycin content and alphaglucosidase inhibitory activity of Thai silkworm races (Bombyx mori Linn.). Pak. J. Pharm. Sci. https://doi.org/10.36721/PJPS. 2019.32.6.REG.2539-2544.1 (2019).

24. Zielińska, E., Baraniak, B. \& Karaś, M. Antioxidant and anti-inflammatory activities of hydrolysates and peptide fractions obtained by enzymatic hydrolysis of selected heat-treated edible insects. Nutrients 9, 970. https://doi.org/10.3390/nu9090970 (2017).

25. Di Mattia, C., Battista, N., Sacchetti, G. \& Serafini, M. Antioxidant activities in vitro of water and liposoluble extracts obtained by different species of edible insects and Invertebrates. Front. Nutr. 6, 106. https://doi.org/10.3389/fnut.2019.00106 (2019).

26. Kwon, M. G. et al. Isolation and analysis of natural compounds from silkworm pupae and effect of its extracts on alcohol detoxification. Entomol. Res. 42, 55-62. https://doi.org/10.1111/j.1748-5967.2011.00439.x (2012).

27. Lin, Y. C., Wu, C. J., Kuo, P. C., Chen, W. Y. \& Tzen, J. T. Quercetin 3-O-malonylglucoside in the leaves of mulberry (Morus alba) is a functional analog of ghrelin. J. Food Biochem. 44, 13379. https://doi.org/10.1111/jfbc.13379 (2020).

28. Nile, S. H., Nile, A. S., Keum, Y. S. \& Sharma, K. Utilization of quercetin and quercetin glycosides from onion (Allium cepa L.) solid waste as an antioxidant, urease and xanthine oxidase inhibitors. Food Chem. 235, 119-126. https://doi.org/10.1016/j.foodc hem.2017.05.043 (2017).

29. Khan, M. A., Shahwar, D., Ahmad, N. \& Ajaib, M. Chemical constituents of Carissa opaca extracts and their evaluation as antioxidants and preservatives in edible oils. Asian J. Chem. 22, 379 (2010). 
30. Haque, M. \& Mahadeva, R. U. Screening of secondary metabolites and comparative superoxide radical scavenging along with reducing potency of Persea americana using various solvent extracts. Drug Invent. 4, 569-574 (2012).

31. Thring, T. S., Hili, P. \& Naughton, D. P. Anti-collagenase, anti-elastase and antioxidant activities of extracts from 21 plants. BMC Compl. Altern. Med. 9, 1-11. https://doi.org/10.1186/1472-6882-9-27 (2009).

32. Baumann, L. Skin ageing and its treatment. J. Pathol. Bacteriol. 211, 241-251. https://doi.org/10.1002/path.2098 (2007).

33. Im, A. et al. Anti-photoaging effects of four insect extracts by downregulating matrix metalloproteinase expression via mitogenactivated protein kinase-dependent signaling. Nutrients 11, 1159. https://doi.org/10.3390/nul1051159 (2019).

34. Polanowski, A. et al. Serine proteinase inhibitor profiles in the hemolymph of a wide range of insect species. Comp. Biochem. Physiol. B. 102, 757-760. https://doi.org/10.1016/0305-0491(92)90075-3 (1992).

35. Phiriyangkul, P., Srinroch, C., Srisomsap, C., Chokchaichamnankit, D. \& Punyarit, P. Effect of food thermal processing on allergenicity proteins in Bombay locust (Patanga succincta). Int. J. Food Eng. 1, 23-28. https://doi.org/10.18178/ijfe.1.1.23-28 (2015).

36. Scott, L. et al. A proposed eye irritation testing strategy to reduce and replace in vivo studies using bottom-up and top-down approaches. Toxicol. In Vitro. 24, 1-9. https://doi.org/10.1016/j.tiv.2009.05.019 (2010).

37. Jeong, K. Y. et al. Role of tropomyosin in silkworm allergy. Mol. Med. Rep. 15, 3264-3270. https://doi.org/10.3892/mmr.2017.6373 (2017).

38. Taylor, G. \& Wang, N. Entomophagy and allergies: A study of the prevalence of entomophagy and related allergies in a population living in North-Eastern Thailand. Biosci. Horizons Int. J. Stud. Res. https://doi.org/10.1093/biohorizons/hzy003 (2018).

39. Brown, R. E., Jarvis, K. L. \& Hyland, K. J. Protein measurement using bicinchoninic acid: Elimination of interfering substances. Anal. Biochem. 180, 136-139. https://doi.org/10.1016/0003-2697(89)90101-2 (1989).

40. Tachakittirungrod, S., Okonogi, S. \& Chowwanapoonpohn, S. Study on antioxidant activity of certain plants in Thailand: Mechanism of antioxidant action of guava leaf extract. Food Chem. 103, 381-388. https://doi.org/10.1016/j.foodchem.2006.07.034 (2007).

41. Chaiyana, W. et al. Inhibition of 5a-reductase, IL-6 secretion, and oxidation process of Equisetum debile Roxb. ex vaucher extract as functional food and nutraceuticals ingredients. Nutrients 9, 1105. https://doi.org/10.3390/nu9101105 (2017).

42. Brem, B. et al. Antioxidant dehydrotocopherols as a new chemical character of Stemona species. Phytochem. 65, 2719-2729. https:// doi.org/10.1016/j.phytochem.2004.08.023 (2004).

43. Saeio, K., Chaiyana, W. \& Okonogi, S. Antityrosinase and antioxidant activities of essential oils of edible Thai plants. Drug Discov. Ther. 5, 144-149. https://doi.org/10.5582/ddt.2011.v5.3.144 (2011).

44. Laothaweerungsawat, N., Sirithunyalug, J. \& Chaiyana, W. Chemical compositions and anti-skin-ageing activities of Origanum vulgare L essential oil from tropical and Mediterranean region. Molecules 25, 1101. https://doi.org/10.3390/molecules25051101 (2020).

45. Somwongin, S., Chantawannakul, P. \& Chaiyana, W. Antioxidant activity and irritation property of venoms from Apis species. Toxicon 145, 32-39. https://doi.org/10.1016/j.toxicon.2018.02.049 (2018).

46. Basketter, D. A. et al. The classification of skin irritants by human patch test. Food Chem. Toxicol. 35, 845-852. https://doi.org/10. 1016/s0278-6915(97)00053-7 (1997).

47. Jirova, D. et al. Comparison of human skin irritation and photo-irritation patch test data with cellular in vitro assays and animal in vivo data. AATEX. 14, 359-365 (2007)

\section{Acknowledgements}

The authors would like to acknowledge the Royal Golden Jubilee Ph.D. Program (RGJ-Ph.D. Program), Grant Number PHD/0118/2561; National Research Council of Thailand (NRCT), and the ASEAN European Academic University Network (ASEA-UNINET) Scholarship. Adchara Prommaban is grateful to CMU Presidential Scholarship 2021 for Post-Doctoral researcher. The APC was funded by Research Center of Pharmaceutical Nanotechnology, Chiang Mai University, Chiang Mai, Thailand and Innovation Center for Holistic Health, Nutraceuticals, and Cosmeceuticals, Faculty of Pharmacy, Chiang Mai University, Thailand.

\section{Author contributions}

Conceptualization, W.C.; investigation, K.Y., C.P, S.S., S.S., and A.P.; writing original draft preparation, K.Y., and W.C.; writing review and editing, K.Y., W.C., S.A., and P.C.; project administration, W.C.; funding acquisition, W.C., K.Y., and P.C. All authors have read and agreed to the published version of the manuscript.

\section{Competing interests}

The authors declare no competing interests.

\section{Additional information}

Correspondence and requests for materials should be addressed to W.C.

Reprints and permissions information is available at www.nature.com/reprints.

Publisher's note Springer Nature remains neutral with regard to jurisdictional claims in published maps and institutional affiliations.

(c) (i) Open Access This article is licensed under a Creative Commons Attribution 4.0 International License, which permits use, sharing, adaptation, distribution and reproduction in any medium or format, as long as you give appropriate credit to the original author(s) and the source, provide a link to the Creative Commons licence, and indicate if changes were made. The images or other third party material in this article are included in the article's Creative Commons licence, unless indicated otherwise in a credit line to the material. If material is not included in the article's Creative Commons licence and your intended use is not permitted by statutory regulation or exceeds the permitted use, you will need to obtain permission directly from the copyright holder. To view a copy of this licence, visit http://creativecommons.org/licenses/by/4.0/.

(C) The Author(s) 2021 